\title{
A review of environmental law in Maldives with respect to conservation, biodiversity, fisheries and tourism
}

\author{
Erika J Techera \\ Professor, UWA Law School and UWA Oceans Institute, The University of Western Australia
}

\author{
Madelaine Cannell-Lunn \\ Graduate Research Assistant, UWA Law School, The University of Western Australia
}

\begin{abstract}
Maldives is a small island developing State in the Indian Ocean comprised of multiple low-lying, sandy islands and coral reefs. It has a long history of human occupation and dependence on the environment, particularly the ocean, for food, resources and trade. Maldives continues to rely upon nature through tourism and fisheries. Conservation and sustainable use of the environment and its resources is therefore of paramount importance to Maldives. In response to growing environmental pressures, including climate change, the State has engaged at global and regional levels, ratifying treaties and participating in key international institutions. It has also developed national law and policy, as well as relevant plans and strategies focused on sustainability. Despite this activity, relatively little legal research has focused on this jurisdiction. This article aims to contribute to the literature on Maldives by exploring environmental, fisheries and tourism laws and policies, analysing current legislative developments and making tentative recommendations in areas where governance could be enhanced.
\end{abstract}

Keywords: environmental law, tourism law, fisheries regulation, Maldives, environmental governance, Indian Ocean

\section{INTRODUCTION}

The Republic of Maldives (Maldives) is a small island developing State (SIDS) located in the Indian Ocean in Southern Asia, south-southwest of India. It is comprised of numerous low-lying islands and atolls. ${ }^{1}$ With limited agricultural land and freshwater, Maldives has relied heavily on marine and coastal areas for food, resources and livelihoods such as fishing. It is the natural environment of sandy beaches, lagoons and species rich reefs which has also led to Maldives being a sought-after holiday destination, and tourism becoming the primary economic activity. This has resulted in a demonstrable shift from consumptive to non-consumptive use of the environment and natural resources that has in turn influenced the development of law and policy.

Despite a long history of human occupation relatively little research has been undertaken on the law and policy context of this nation. Early studies of the country

1. UNEP/SACEP/NORAD (2001), Handbook on National Environmental Legislation and Institutions in the Maldives <www.sacep.org/pdf/Reports-Technical/2001-UNEP-SACEPLaw-Handbook\%20-Maldives.pdf>. 
focused on anthropology and archaeology, then science and sustainability, but rarely upon the law. ${ }^{2}$ The history of Maldives has resulted in a legal system that is Islamic with some British common law influences, making it an interesting jurisdiction in its own right. More particularly, Maldivian legal responses to environmental concerns are worthy of exploration given the vulnerability of these small islands, the country's heavy dependence on natural resources for economic activities, and the limited financial and technical resources available to address challenges.

This paper contributes to the literature by providing a review of Maldivian environmental, fisheries and tourism law and policy. The research is centred on a deskbased analysis of primary sources, as well as the limited secondary literature on Maldivian law. Lack of access to materials and language barriers have prevented analysis of some of the most recent legislative and case law developments, and therefore this article provides a first step towards greater understanding of this jurisdiction. ${ }^{3}$ No empirical fieldwork was undertaken, and further research is needed to analyse the extent to which legislation has been implemented and its effectiveness; this article provides a firm foundation for such research. The article commences with a consideration of the natural environment and historical factors that have contributed to the development of law in Maldives. The laws and policies themselves are then explored in detail, followed by an analysis of challenges and opportunities as well as tentative recommendations of areas where law, policy and governance might be enhanced.

\section{BACKGROUND TO THE MALDIVES}

\subsection{Geography and biodiversity}

Maldives is comprised of 1192 coral islands in a double chain of 26 atolls with a total land area is $300 \mathrm{sq} \mathrm{km} .{ }^{4} 90$ percent of the islands have a land area less than $0.5 \mathrm{sq} \mathrm{km}$, with the largest island being approximately $6 \mathrm{sq} \mathrm{km}$, and 80 percent of the islands are one metre or less above sea level. ${ }^{5}$ Maldives' marine area is much larger, with its Exclusive Economic Zone (EEZ) covering almost one million sq $\mathrm{km} .{ }^{6}$ The coral reefs and sand islands that form Maldives are located on a submarine ridge formed on ancient, now sunken, volcanoes. Because of the small land area and poor soils,

2. See for example, Clarence Maloney, 'The Maldives: New Stresses in an Old Nation' (1976) 16(7) Asian Survey 654-71; Thor Heyerdahl, The Maldive Mystery (George Allen \& Unwin, 1986); Karl E Ryavec, 'Maldives' in Helen Chapin Metz (ed), Indian Ocean: Five Island Countries (Library of Congress, 1994); Fathimath Ghina, 'Sustainable Development in Small Island Developing States: The Case of Maldives' (2003) 5 Environment, Development and Sustainability 139-65. A rare exception is the UNEP/SACEP/NORAD Handbook (n 1), but this is now considerably out of date.

3. The challenges posed by a number of documents only available in the local language, Dhivehi, has been noted by other researchers: Aishath Shakeela, Susanne Becken and Nicole Johnston, Gaps and Disincentives that Exist in the Policies, Laws and Regulations Which Act As a Barrier to Investing in Climate Change Adaptation in the Tourism Sector of the Maldives (Ministry of Tourism, 2015) 14.

4. Republic of Maldives Ministry of Environment and Energy, National Biodiversity Strategy \& Action Plan 2016-2025 (NBSAP) (2015) 6.

5. Ryavec (n 2) 251. The highest island is 3 metres above sea level: ibid, 262.

6. M Shiham Adam, Country Review: Maldives <www.fao.org/docrep/009/a0477e/ a0477e0y.htm>. 
terrestrial species diversity is limited, but is much greater with respect to marine animals as well as birds. ${ }^{7}$ Maldives has no hills or rivers, and freshwater is limited to a subterranean lens floating above the seawater. ${ }^{8}$ The vegetation largely comprises breadfruit trees and coconut palms. Because the soil is sandy and alkaline, agricultural potential is severely limited with the most fertile island being Fua Mulaku, in part because it is higher than other islands.

\subsection{Pattern of settlement}

People are believed to have ventured to Maldives at least since $500 \mathrm{BCE}^{9}$ and possibly as early as 2000 BCE, via maritime trading routes established by Egyptian, Mesopotamian and Indus Valley civilisations. ${ }^{10}$ Traders and travellers continued to visit Maldives, and it became the main source of cowrie shells, in use as currency in Asia and Africa. ${ }^{11}$ Settlers from Sri Lanka arrived next and by the fourth century AD Theravada Buddhism dominated in Maldives. ${ }^{12}$ Arabs were the 'last main group to arrive beginning in the ninth century' ${ }^{13}$ and by the tenth century AD the Middle Eastern seafarers began to dominate. Although there are still traces of preIslamic settlers, the last Buddhist King in Maldives converted to Islam in $1153 .{ }^{14}$ After the sixteenth century, Maldives was technically under Portuguese, ${ }^{15}$ Dutch $^{16}$ and then British ${ }^{17}$ control, but was largely self-governed by the Sultans until the 1932 when the sultanate became elective. Islam continued as the main religion with the oldest remaining mosque in Maldives dating back to $1656 .{ }^{18}$ The British were the last colonial power and even after Maldivian independence in 1965, continued to have a presence until $1976 .{ }^{19}$ Maldives officially abolished the sultanate in 1968 and established a republic.

7. Maldives is home to 20 species of whales and dolphins, 40 species of sharks and over 167 species of birds as well as 14 species of mangrove: NBSAP (n 4) 6. For details of endemic species, see Republic of Maldives Ministry of Environment and Energy, State of the Environment Report $2016<$ file://uniwa.uwa.edu.au/userhome/staff4/00078414/Downloads/20170202-PubState_of_the_Environment_2016\%20(3).pdf>.

8. Ryavec (n 2) 263.

9. Michael Pearson, The Indian Ocean (Routledge, 2003) 261.

10. Ryavec (n 2) 258 .

11. It is said that the 'best' money cowrie came from Maldives: Pearson (n 9) 84-85. See also Ryavec (n 2) 257. Cowrie shell collecting was a woman's task: Ryavec (n 2) 277.

12. Ibid, 258.

13. Ibid, 265.

14. Ibid, 258.

15. There was a period of Portuguese occupation from 1558-73 until Muhammad Thakurufaan drove them out; but even during that period Maldives was administered from Goa in India: ibid, 257 and 259.

16. The Dutch dominated Maldivian affairs but allowed local matters to be governed according to Islamic customs: ibid, 259.

17. The British drove the Dutch from Sri Lanka in 1796 and officially recorded Maldives as a British Protectorate in 1887 but again had no physical presence and left the Maldivians to selfgovern through the Sultanate until 1965: ibid, 259.

18. Ibid, 258.

19. Ibid, 257. 


\subsection{Demographics}

The pattern of settlement of Maldives has shaped the population and culture today. The people, for example, have been described as an "homogeneous mixture of Sinhalese, Dravidian, Arab, Australasian and African groups' ${ }^{20}$ Ethnically, the country is composed of South Indians, Sinhalese and Arabs. Dhivehi (the official dialect of Sinhala and the script derived from Arabic), and English are the official languages. Maldivians are Sunni Mus$\mathrm{lim}$, and this has influenced the Maldivian legal system, which is based on Sharia Law. ${ }^{21}$ Nevertheless, 'isolation ... from the historical centers of Islam in the Middle East and Asia has allowed some pre-Islamic beliefs and attitudes to survive'. ${ }^{22}$

Today Maldives has a population of just under 400,000 and one of the lowest population growth rates in the world. ${ }^{23}$ This population mostly live in the city of Malé on one island, which at over 1,100 people per sq km has one of the highest densities in the world. Maldives also has a high unemployment and death rate. ${ }^{24}$

\subsection{Economy}

The combination of limited availability of cultivable land and shortage of domestic labour constrain the role of agriculture and manufacturing. Maldives is a SIDS and was one of the world's least developed countries until 2009, and it still has one of the lowest GDPs in the world. ${ }^{25}$

Fishing has historically been the main source of economic earnings. It is now the second largest economic activity, having reduced significantly in recent years. Previously Maldives had exported 90 percent of its fish to Sri Lanka in dried form, but in the 1970s that country cut back on imports impacting significantly on the Maldivian economy. ${ }^{26}$ Nonetheless, tuna remains the most important export commodity earning 160 million USD annually. ${ }^{27}$ Tourism is now Maldives' leading economic sector at 28 percent of GDP, exceeding fisheries for the first time in $1989 .{ }^{28}$ It has been noted that the large revenue base generated by tourism could have facilitated greater levels of development in the country, but lack of investment in socioeconomic areas and poor governance have hampered long-term progress. ${ }^{29}$ The extent

20. Ibid, 251.

21. Ibid, 257 and 268 .

22. Ibid, 268. This includes widespread beliefs in jinns or evil spirits and magico-religious fandita.

23. The World Bank, 'Population growth (annual \%)', <https://data.worldbank.org/indicator/ SP.POP.GROW?end=2017\&locations $=$ MV\&start $=1960 \&$ view $=$ chart $>$.

24. National Bureau of Statistics, 'Statistical Pocketbook of the Maldives 2016' <http://statisticsmaldives.gov.mv/nbs/wp-content/uploads/2017/01/Statistical-Pocketbook-2016-final-10Jan-2016.pdf>.

25. Ibid.

26. Hussain Sinan, Background Report of Fishery Products, The Maldives, (Ministry of Fisheries and Agriculture, undated) <www.fao.org/fileadmin/user_upload/fisheries/docs/Maldives_ Edited_docx $>, 8$.

27. Ministry of Fisheries and Agriculture, Republic of Maldives, Maldives National Report submitted to the Indian Ocean Tuna Commission Scientific Committee (2015) <www.fao. org/3/a-bf553e.pdf>.

28. Ryavec (n 2) 274.

29. Athaulla A Rasheed, 'Historical Institutionalism in the Maldives: A Case of Governance Failure The Maldives' (2014) 2(1) National Journal of Research 7-28. 
of economic reliance on the marine environment is highlighted by the coral bleaching event of 1998-99, which is estimated to have cost Maldives economy 36 million USD in lost tourism and fisheries revenue. ${ }^{30}$

This history provides a rationale for the focus in this article on environment, fisheries and tourism law. It also explains in part the early intersection of tourism and conservation, and why tourism regulations and institutions emerged in Maldives to a greater extent than in other States. ${ }^{31}$

\subsection{Politico-legal landscape}

Maldives has been dominated by only a select few political figures. President Maumoon Abdul Gayoom was elected to six successive terms by single-party referendums. ${ }^{32}$ In the past, political parties were 'officially discouraged as contrary to homogeneity' but in 2003 the President embarked on democratic reforms, culminating in the legalisation of other political parties in 2005. In the context of a period of unrest, a new Constitution was finalised in 2008 and ratified by the President. ${ }^{33}$ Maldives' first-ever multi-candidate multi-party presidential elections were held in October 2008. Nevertheless, the political climate remains volatile with ongoing allegations of corruption.

Today Maldives has a centralised presidential system of government. The President is elected for renewable five-year terms and is both chief of State and the head of the government. There is a unicameral legislative People's Council (Majlis), which comprises of two elected members from each of the administrative atolls and Malé, and one additional member for each group of 5,000 exceeding the first 5,000. ${ }^{34}$

Administratively, Maldives' 1192 coral islands and 26 atolls are organised into 20 administrative divisions. ${ }^{35}$ Each island has a chief, khatib, and each atoll is administered by the atolu verin (atoll chief) and gazi (religious leader). ${ }^{36}$ At the national level, administration is divided amongst a number of ministries. Environmental concerns were first elevated to ministerial level in 1998 with the establishment of the Ministry of Planning and the Environment. ${ }^{37}$ The current administrative structure is outlined below.

30. Pearson (n 9) 278.

31. The tourism industry's focus on environmental conservation commenced in the 1980s as evidenced by the adoption of the First Tourism Master Plan: Ministry of Tourism, Arts \& Culture, Republic of Maldives, Fourth Tourism Master Plan, Volume 2 Background and Analysis <www.tourism.gov.mv/downloads/news/2012/4TMP_DRAFT_Vol_2_BACKGROUND_ ANALYSIS.pdf $>, 145$.

32. Department of Foreign Affairs and Trade, Maldives Country Brief $<$ https://dfat.gov.au/ geo/maldives/Pages/maldives-country-brief.aspx $>$.

33. Republic of Maldives Ministry of Legal Reform, Information and Arts, Constitution of the Republic of Maldives 2008 <www.majlis.gov.mv/en/wp-content/uploads/Constitution-english. pdf>.

34. Mariyam Zulfa, From Big Bang to Incrementalism: Choices and Challenges in Constitution Building (The 2nd Melbourne Forum on Constitution Building in Asia and the Pacific, 3-4 October 2017) 2.

35. International Foundation for Electoral Systems, Election Guide: Republic of Maldives $<$ www.electionguide.org/elections/id/2453/>; Zulfa (n 34) 1.

36. Ryavec (n 2) 267. The family is the basic unit of society.

37. UNEP/SACEP/NORAD (n 1) 11. 
Maldives has an Islamic religious legal system with British common law influences (primarily in commercial law). The Supreme Court is Maldives' highest court consisting of six justices and a chief justice. In addition, each inhabited island has a system of subordinate courts: High Court; Criminal, Civil, Family, Juvenile and Drug Courts; and Magistrate Courts. ${ }^{38}$ Ultimately, final authority rests with the President who appoints all judges in consultation with the Judicial Service Commission. ${ }^{39}$ Thus the courts are not fully independent.

\subsection{Use of natural resources}

Historically, land-based activities such as coral and sand mining for building materials, ${ }^{40}$ harvesting of fuel wood leading to deforestation, and degradation of the limited freshwater resources all impacted upon Maldives. ${ }^{41}$ By the turn of the twenty-first century the main environmental issues were identified as depletion of freshwater, and the impacts of climate change: sea level rise, global warming and coral reef bleaching, although issues such as coral mining remain a concern at the local level. ${ }^{42}$ In addition, waste management, with issues such as land-based marine plastic pollution, is a significant challenge requiring enhanced regulation and legislation, but it is not the focus of this paper. Particular biodiversity conservation issues include land reclamation involving shallow reefs, protection of endangered species, compliance and enforcement. ${ }^{43}$

As noted above, Maldives first attracted interest because of its abundance of valuable cowrie shells. From then on fishing strongly dominated in Maldives. In 1979, the government formed the Maldives Fishing Corporation to exploit these resources. ${ }^{44}$ Tuna has been the dominant fishery in the country, which provided the majority of the catch for centuries. Maldives still has a significant tuna fishing industry ${ }^{45}$ dominated by the live bait pole and line fishery, but also including handline, longlining and trolling. ${ }^{46}$ Nets are not permitted, in favour of more labour intensive, traditional methods. ${ }^{47}$ Licensing of foreign longline fishing was discontinued in 2010, and in 2012 a domestic longline fishery was established. ${ }^{48}$ A grouper fishery was commenced in 1992 and other products include sea cucumber and export of live ornamental fish. ${ }^{49}$

38. The World Law Guide, Courts and Cases Maldives <www.lexadin.nl/wlg/courts/nofr/ oeur/lxctmdv.htm>.

39. A separate body of selected high government officials and the public.

40. Pearson (n 9) 39.

41. UNEP/SACEP/NORAD (n 1) 1 .

42. Ibid, 35 .

43. Ibid, 63-64.

44. FAO, Maldives and FAO: Achievements and Success Stories (2011) <www.fao.org/3/aat010e.pdf $>, 2$.

45. Skipjack tuna comprises 70 percent of the total catch with yellow fin tuna the second largest species caught, growing in importance given its higher value: FAO, Fishery and Aquaculture Country Profiles: The Republic of Maldives (2009) <www.fao.org/fishery/facp/MDV/en>.

46. Ministry of Fisheries and Agriculture (n 27).

47. FAO (n 44).

48. Ibid, 4. See also Kelsey I Miller, Ibrahim Nadheeh, A Riyaz Jauharee, R Charles Anderson and M Shiham Adam, 'Bycatch in the Maldivian Pole-an-line Tuna Fishery' (2017) 12(5) PLoS ONE 1-21, doi: 10.1371/journal.pone.0177391.

49. UNEP/SACEP/NORAD (n 1) 64-65. 
Use of natural resources shifted from consumptive to non-consumptive exploitation in the 1970s when visitors became attracted to Maldives. Tourism has expanded rapidly since then, from 1,062 visitors in 1972, to 120,000 in 1985 and 1.2 million in 2014. ${ }^{50}$ Today, 111 enclave resorts now operate across Maldives, together with vessel-based accommodation, hotels and guesthouses. ${ }^{51}$ As noted above, since 1989 tourism has been the most important economic sector in Maldives. This has resulted in changing attitudes towards the marine environment.

The move towards conservation of the marine environment is illustrated by the example of sharks. It is said that a traditional shark fishery (maakeyolhu kan) existed perhaps for millennia. Shark livers were originally the target as the oil was used to treat the hulls of traditional wooden fishing vessels. In the latter half of the twentieth century this changed with a greater focus on meat and fins as technology improved and the global market for shark products evolved. More recently, Maldives has radically shifted its approach to sharks and today, diving and swimming with whale sharks is one of the many tourism activities available in Maldives and is of considerable economic value. The attitude towards sharks is just one example of the changing nature of environmental governance in Maldives.

This brief historical analysis provides the background to Maldives' use and continued reliance upon its natural resources, as well as the impetus for action to conserve the species and habitats for both the tourism and fisheries sectors. The geography and biodiversity has shaped Maldives' development and economy, but also its engagement with environmental law. As will be seen below, this small nation has engaged broadly with international environmental law regimes focused on marine conservation, fisheries and climate change; unsurprising given that these are significant concerns.

\section{MALDIVES IN AN INTERNATIONAL CONTEXT}

Maldives joined the United Nations (UN) in 1965, shortly after independence. Since then it has been an active member of the global community, ratifying the majority of international environmental conventions and being particularly vocal in the context of climate change. Maldives has also embraced the 17 Sustainable Development Goals (SDGs), which provide targets and indicators across a range of sectors. It has done this by, for example, creating a SDG Division under the Ministry of Environment and Energy and a SDGs Technical Committee, integrating SDGs into local development strategy and tasking the National Bureau of Statistics to identify and assess data gaps ${ }^{52}$ As the SDGs are not legally binding, Maldives' strong engagement with them further highlights its active global involvement.

Set out below are the binding instruments that relate to environmental conservation, fisheries and tourism; though it should be noted that Maldives has also ratified a number of pollution treaties not considered here. ${ }^{53}$ The commitment to the environment can be seen through the announcement by the President, and endorsement by

50. Republic of Maldives (n 7) 28.

51. Ibid. See also Shakeela et al (n 3) 9. Enclave tourism is practised in few places apart from the Maldives, and involves islands developed for tourists being off limits to local people.

52. UN, Maldives: Taking Action for Sustainable Development <www.un.org/sustainabledevelopment/wp-content/uploads/2017/07/Maldives_Government.pdf>.

53. For further detail see UNEP/SACEP/NORAD (n 1). 
Cabinet, of the intention to make the whole country a Biosphere Reserve by $2017 .{ }^{54}$ Although this has yet to be realised, it demonstrates continuing efforts to strengthen environmental governance.

\subsection{Environmental law}

Maldives has signed the Stockholm Declaration ${ }^{55}$ and the Rio Declaration ${ }^{56}$ and committed to sustainable development, as well as the other critical environmental principles, implemented in policies and domestic legislation such as the Environment Protection and Preservation Act (Law No. 4/93) (EPPA).

One of the first environmental treaties that Maldives signed was the World Heritage Convention. ${ }^{57}$ Maldives has no listed sites but does have the unique Coral Stone Mosques on the Tentative List, illustrating Buddhist/Islamic cultural fusion. ${ }^{58}$ Surprisingly, Maldives has not sought to nominate any natural heritage areas. Obligations have been implemented in the Law No. 27/79 of historical and cultural properties of the Republic of Maldives (1979) as well as the EPPA, explored further below.

Most significantly in terms of wildlife conservation, Maldives has ratified the Convention on Biological Diversity, ${ }^{59}$ and responded to its obligations developing its first biodiversity strategy in $2001^{60}$ and submitting five National Reports to date. ${ }^{61}$ The latest National Report notes current challenges and efforts to enhance environmental governance, including in the area of law and regulation. ${ }^{62}$ Maldives' current policy instrument is the National Biodiversity Strategy and Action Plan 2016-2025 (NBSAP), which recognises the need for conservation and sustainable use of biodiversity and refers specifically to further strengthening of law and governance (considered below). Maldives is not a party to the Nagoya Protocol on Access and Benefit Sharing. ${ }^{63}$

Maldives is a party to the Convention on International Trade in Endangered Species (CITES). This provides a framework for regulating import and export of listed species. In terms of implementation of its obligations, the NBSAP makes specific reference to the fact that Maldives is preparing its regulations to implement the provisions of CITES. ${ }^{64}$ Interestingly, Maldives is not a party to two other treaties that

54. NBSAP (n 4) 5.

55. Stockholm Declaration on the Human Environment, 16 June 1972, UN Doc A/CONF.48/ 14 (1972).

56. Rio Declaration on Environment and Development, Report of the United Nations Conference on Environment and Development, (1992) UN Doc A/CONF.151/6/Rev.1.

57. Convention for the Protection of the World Cultural and Natural Heritage adopted at Paris on 16 November 1972, 1037 UNTS 151 (World Heritage Convention).

58. World Heritage Convention, Coral Stone Mosques of Maldives <http://whc.unesco.org/ en/tentativelists/5812/>.

59. Convention on Biological Diversity adopted at Rio de Janeiro on 5 June 1992, 1760 UNTS 79 (CBD).

60. UNEP/SACEP/NORAD (n 1) 65.

61. Convention on Biological Diversity, National Reports and NBSAPs <www.cbd.int/ reports/search/>.

62. Ministry for Environment and Energy, Republic of Maldives, Fifth National Report of Maldives to the Convention on Biological Diversity (2015).

63. It has been noted that the weak legal framework on genetic resources may result in economic loss: ibid, 53.

64. NBSAP (n 4) 10. 
would appear to be of relevance: Ramsar Convention on Wetlands of International Importance (Ramsar Convention) ${ }^{65}$ and the Convention on Migratory Species (Migratory Species Convention). ${ }^{66}$ The Ramsar Convention provides a framework for international listing of wetlands, defined as including marine areas around islands to a depth of 5 metres. The Migratory Species Convention provides a regime for the listing of species that range across multiple States, and thereafter encourages multi-lateral cooperative conservation by those States. Given that Maldives has a diverse range of marine megafauna and migratory birds - and has made significant efforts to advance shark conservation - this treaty would appear highly relevant. The NBSAP refers to these treaties, noting that the plan will also contribute to the goals of the Migratory Species Convention and Ramsar Conventions to which Maldives is not yet a party. ${ }^{67}$

Climate change poses significant challenges for a State like Maldives. Therefore, it is unsurprising that the country was an early signatory to the UN Framework Convention on Climate Change ${ }^{68}$ and Kyoto Protocol ${ }^{69}$ in 1992 and 1998 respectively. Maldives is also a signatory to the Paris Agreement, and in 2015 submitted the Maldives' Intended Nationally Determined Contribution (INDC). The INDC confirms that Maldives is totally dependent on imported fossil fuels, and therefore prioritises the development of domestic clean energy resources. The majority of the country's mitigation efforts are in this area. In terms of adaptation, the focus is upon food and water security, and building critical infrastructure resilience to protect against the impacts of climate change. The document refers to the negative impacts of climate change on coral reefs (critical for tourism) and tuna (important to the fisheries sector). One reference is made to the law, with the commitment to develop a Climate Change Act. ${ }^{70}$ Even before the adoption of the Paris Agreement, Maldives had already developed a National Adaptation Programme of Action in 2006 which recognised the role of law and regulation, and subsequently also prepared a Strategic National Action Plan for Disaster Risk Reduction and Climate Change Adaptation 2010-2020.

\subsection{Law of the sea and fisheries regulation}

The UN Convention on the Law of the Sea (UNCLOS) ${ }^{71}$ sets out agreed maritime zones including coastal States' EEZs. UNCLOS provides rights to explore and exploit, as well as obligations to protect and preserve the marine environment. Maldives is a party to UNCLOS and deposited its submission on the Maldivian territorial

65. Convention on Wetlands of International Importance especially as Waterfowl Habitat, adopted at Ramsar on 2 February 1971, 996 UNTS 245 (Ramsar Convention).

66. Convention on the Conservation of Migratory Species of Wild Animals, adopted at Bonn on 23 June 1979, 1651 UNTS 356 (CMS).

67. NBSAP (n 4) 4.

68. United Nations Framework Convention on Climate Change, adopted at Rio de Janeiro on 9 May 1992, 1771 UNTS 107 (UNFCCC), art 3(1).

69. Protocol to the United Nations Framework Convention on Climate Change, adopted at Kyoto on 11 December 1997, 2303 UNTS 162 (Kyoto Protocol).

70. Government of Maldives, Ministry of Environment and Energy, Maldives' Intended Nationally Determined Contribution (INDC) 11. See also Shakeela et al (n 3) 1, where it is argued that such legislation needs to be given urgent priority.

71. United Nations Convention on the Law of the Sea, adopted at Montego Bay on 10 December 1982, 1833 UNTS 3 (UNCLOS). 
boundaries and the outer limits of its continental shelf in $2010{ }^{72}$ The Maritime Zones of Maldives Act (Law No. 6/96) operationalises the zoning provisions of UNCLOS. Maldives has presumably utilised UNCLOS to discontinue foreign fishing licences in the EEZ and establish a domestic longline fishery. Supplementary to UNCLOS is the UN Fish Stocks Agreement (FSA). ${ }^{73}$ This instrument supplements UNCLOS with specific provisions relating to migratory and straddling stocks. This is relevant to Maldives given the significance of tuna to the fisheries sector. The FSA incorporates the precautionary principle and provides for the effects of fishing and other anthropogenic activities as well as environmental factors in setting total catches. It emphasises the role of Regional Fishery Management Organisations (RFMOs), one of which is relevant to Maldives: Indian Ocean Tuna Commission. ${ }^{74}$

Maldives joined the Food and Agriculture Organisation (FAO) in 1971 and has cooperated with it since then through, for example, acceptance of the Code of Conduct for Responsible Fisheries. ${ }^{75}$ As noted above, the FAO has taken the lead on shark conservation adopting the International Plan of Action on Sharks in 1999. Maldives is a signatory and has developed its own National Plan of Action for the Conservation and Management of Sharks in the Maldives in 2015. ${ }^{76}$

\subsection{Tourism}

There is no international tourism treaty and the only relevant body is the UN World Tourism Organisation (UNWTO) responsible for the "promotion of responsible, sustainable and universally accessible tourism'. ${ }^{77}$ Maldives is a Member State of the UNWTO and has participated in initiatives such as an executive training programme on tourism policy and strategy. ${ }^{78}$ The lack of global guidance on tourism governance means that much is left to individual States to prepare at the domestic level. Interestingly, Maldives has developed specific tourism legislation, unlike many of its regional neighbours. This is explored in the sections that follow.

72. Republic of Maldives, Submission by the Republic of Maldives to the Commission on the Limits of the Continental Shelf <www.un.org/depts/los/clcs_new/submissions_files/mdv53_10/ MAL-ES-DOC.pdf>.

73. Agreement for the Implementation of the United Nations Convention on the Law of the Sea of 10 December 1982 Relating to the Conservation and Management of Straddling Fish Stocks and Highly Migratory Fish Stocks, adopted at New York on 4 August 1995, 2167 UNTS 3 (Fish Stocks Agreement).

74. IOTC, Compliance report for Maldives <IOTC-2018-CoC15-CR15E-Maldives.pdf $>$.

75. FAO (n 44). See also Robert Gillett, A Riyaz Jauharee and M Shiham Adam, Maldives livebait fishery management plan (Marine Research Centre, Ministry of Fisheries and Agriculture, Maldives, 2013) <http://mrc.gov.mv/assets/Uploads/2013-Baitfishery-Management-Plan2013.pdf>.

76. Republic of Maldives Ministry of Fisheries and Agriculture, National Plan of Action for the Conservation and Management of Sharks in the Maldives (2015) <www.fao.org/3/aaz641e.pdf $>$.

77. UNWTO, 'Who we are' <www2.unwto.org/content/who-we-are-0>.

78. UNWTO '12th UNWTO Asia/Pacific Executive Training Programme on Tourism Policy and Strategy' <http://asiapacific.unwto.org/event/12th-unwto-asiapacific-executive-trainingprogramme-tourism-policy-and-strategy>. 
Table 1 Key treaties and ratification dates

\begin{tabular}{|c|c|c|c|c|c|c|c|}
\hline TREATY & Ramsar & WHC & CITES & CMS & $\begin{array}{c}\text { UNCLOS } \\
+ \text { FSA }\end{array}$ & $\begin{array}{l}\text { CBD + Cartagena } \\
\text { Protocol } \\
+ \text { Nagoya } \\
\text { Protocol }\end{array}$ & $\begin{array}{c}\text { UNFCCC + Kyoto } \\
\text { Protocol + Paris } \\
\text { Agreement }\end{array}$ \\
\hline DATE & Not ratified & 1986 & $2012 ? 2013$ & Not ratified & $\begin{array}{l}2000 \\
+1998\end{array}$ & $\begin{array}{l}1992+2002 \\
+ \text { Not ratified }\end{array}$ & $\begin{array}{l}1992+1998 \\
+2016\end{array}$ \\
\hline
\end{tabular}

\section{MALDIVES AND REGIONAL INITIATIVES}

Maldives falls within the South Asian region along with India, Pakistan, Sri Lanka, Afghanistan, Bangladesh, Bhutan and Nepal. Although these States have common environmental and natural resource problems, the difference in geography and scale require differing responses. Maldives is the only SIDS in this region.

At the regional level Maldives is a founding member of the South Asian Association for Regional Cooperation (SAARC) established in 1983. The focus of SAARC is economic cooperation but it does have a Committee on Environment. ${ }^{79}$

Maldives has benefited from membership of the South Asia Co-operative Environment Programme (SACEP), including through the analysis of national environmental laws. ${ }^{80}$ SACEP supports and promotes environmental protection and management in the region with a focus on regionally relevant issues and cooperation amongst members. ${ }^{81}$ One of the highlights of SACEP's work has been the establishment of a Regional Seas Action Plan for South Asia.

Maldives is also a member of the Bay of Bengal Programme, and the Bay of Bengal Large Marine Ecosystem Project is another relevant regional initiative. ${ }^{82} \mathrm{Com}$ menced with the assistance of the FAO, it focuses on food security and livelihoods through sustainable development and good governance involving community-based participation. ${ }^{83}$ It is this project that assisted Maldives to prepare its National Plan of Action for Sharks. ${ }^{84}$

Unsurprisingly, Maldives has been active in the Association of Small Island States (AOSIS) in the context of climate change negotiations, along with other SIDS facing similar challenges. ${ }^{85}$ Maldives has also benefited from membership of the Asian Development Bank with a number of relevant projects being funded, assisting the country to move from being a least developed country. ${ }^{86}$ In particular, the Environmental Impact Assessment Regulations (2007) were developed through an ADB project. Interestingly, Maldives is not a member of the Association of South East Asian Nations (ASEAN) nor the Indian Ocean Rim Association (IORA).

79. SAARC, Technical Committees <www.saarc-sec.org/Technical-Committees/72/>.

80. UNEP/SACEP/NORAD (n 1).

81. Ibid, 23.

82. See 'Bay of Bengal Programme Intergovernmental Organisation' <www.bobpigo.org/>; 'Bay of Bengal Large Marine Ecosystem Project' <www.bobpigo.org/>.

83. FAO (n 44).

84. Republic of Maldives (n 76).

85. AOSIS <http://aosis.org/>.

86. ADB, 'Maldives: Development Effectiveness Brief' <www.adb.org/publications/ maldives-and-adb-linking-islands $>$. 


\section{DOMESTIC LAW AND POLICY}

The current administrative structure in Maldives includes three relevant ministries: Ministry for Environment and Energy, Ministry for Fisheries, Agriculture and Marine Resources, and the Ministry of Tourism. The development of policies and plans falls to each of these Ministries, and the departments beneath them, within their respective portfolios. The Environmental Protection Agency takes the lead on enforcement with assistance from Maldives Police Services and Maldives Customs Service. Decentralised governance also has a role to play and are likely to increasingly influence the law given the Act on Decentralisation of the Administrative Divisions of the Maldives (Law No. 7/2010) and empowers islands, atolls and city councils to adopt regulations and policies. ${ }^{87}$

The 2008 Constitution of Maldives includes a 'fundamental duty of the state to protect and preserve the biodiversity, resources and beauty of the country for the benefit of present and future generations' as well as ensuring every citizen has the right to a safe environment. ${ }^{88}$ This provides a foundation for strengthening environmental regulation, nonetheless it is clear that environmental, fisheries and tourism laws existed before this inclusion. As noted above, Maldives has an Islamic-based legal system. Given, however, that environmental and natural resources law is largely driven by international developments and/or is of relatively contemporary origins, the influence of Sharia law is not as evident as in other areas. As set out in Table 2, there are only a few major pieces of legislation in Maldives relevant to this paper, with subsidiary regulations under each. These instruments are considered in detail below together with relevant policies - in all areas of environment, fisheries and tourism - as well as plans and programs flowing from them and in response to international law obligations.

\subsection{Environmental law and policy}

The principal environmental law in Maldives is the EPPA. This is a broad statute that includes within it biodiversity and species conservation, environmental impact and land use development. The detailed provisions, however, are set out in separate subsidiary regulations; all of which are considered below. In addition, the Maldivian Land Act (Law No. 1/2002) is relevant in as much as it provides for the allocation of land for various uses: residential, commercial, social, recreational, government and 'environmental protection'. ${ }^{89}$ The Act provides rules for the ownership and leasing of land, and that the government owns all 'natural resources and gold, silver, jewelry, money, utensils, historical artifacts and metals that do not have a legal owner' 90 and that finds must be reported. ${ }^{91}$ This Act contains no specific provisions expanding on allocations of land for environmental protection; nor do there appear to be any associated Regulations. It is clear, however, that this Act works in tandem with the EPPA.

87. Shakeela et al (n 3) 11-12. Councils' influence may be limited given that these bodies do not have financial independence: ibid, 23. See also Draft Act on Decentralization of the Administrative Divisions of the Maldives (2010) <www.shareefweb.com/documents/LocalGovReforms/MaldivesDraftlaw\&regulations/Draft $\% 20$ Translation $\% 20 \mathrm{of} \% 20$ decentralisation $\% 20$ ActMaldives.pdf>; UNICEF, Study on the Decentralization Process in the Maldives (2013) $<$ www.unicef.org/maldives/2013_Decentralization_Study_Final.pdf $>, 43$.

88. Republic of Maldives Constitution 2008 art 22.

89. Maldivian Land Act (Law No. 1/2002) s 4.

90. Maldivian Land Act (Law No. 1/2002) s 38(a). Ownership of coconut palms is excluded.

91. Maldivian Land Act (Law No. 1/2002) s 38(b). 
Table 2 Legislation and Policy in Maldives

\begin{tabular}{|c|c|c|}
\hline & STATUTE & ASSOCIATED REGULATIONS \\
\hline ENVIRONMENT & $\begin{array}{l}\text { Environmental } \\
\text { Protection and } \\
\text { Preservation Act } \\
\text { of Maldives (Law No. 4/93) }\end{array}$ & $\begin{array}{l}\text { Environmental Impact Assessment } \\
\text { Regulations, (2007, R-27/2012 } \\
\text { and R-18/2013) } \\
\text { Regulation on Migratory Birds } \\
\text { (2007) } \\
\text { Regulation on Cutting, Uprooting, } \\
\text { Removing and Transfer of Palms } \\
\text { and Trees between Islands (2006) } \\
\text { Regulation for Determination of } \\
\text { Penalties and Obtaining } \\
\text { Compensation for Damages } \\
\text { Caused to the Environment (2011) } \\
\text { Regulation Governing Reclamation } \\
\text { and Dredging of Islands and } \\
\text { Lagoons of Maldives (R-15/2013) } \\
\text { Regulation for the Protection } \\
\text { and Preservation of Areas } \\
\text { Surrounding Baa Atoll Hanifaru } \\
\text { Island (2012) }\end{array}$ \\
\hline \multirow[t]{2}{*}{ FISHERIES } & $\begin{array}{l}\text { Fisheries Law of the Maldives } \\
\text { (Law No. 5/87) }\end{array}$ & $\begin{array}{l}\text { General Fisheries Regulations } \\
\text { (2000) } \\
\text { Regulation for Issuing the License to } \\
\text { Fish in the Exclusive Economic } \\
\text { Zone of the Republic of Maldives } \\
\text { The Aquaculture Regulations } \\
\text { The Regulation on the Undertaking } \\
\text { of Marine Scientific Research in } \\
\text { the Maldives }\end{array}$ \\
\hline & $\begin{array}{l}\text { Fishing in the Lagoons of } \\
\text { Maldives (Law No. 1/74) }\end{array}$ & \\
\hline TOURISM & $\begin{array}{l}\text { Maldives Tourism Act (Law } \\
\text { No. 2/99) }\end{array}$ & $\begin{array}{l}\text { Regulation on the Protection and } \\
\text { Conservation of Environment in } \\
\text { the Tourism Industry (2006) } \\
\text { Maldives Recreational Diving } \\
\text { Regulation (2003) } \\
\text { Lagoon Zoning Regulation of } \\
\text { Leased Islands for Development of } \\
\text { Tourist Resorts, Tourist Hotels, } \\
\text { Tourist Guesthouse and Yacht } \\
\text { Marina (R-17/2012) }\end{array}$ \\
\hline
\end{tabular}

The EPPA is the key biodiversity law and also provides for protected areas and environmental impact assessment (EIA) of development proposals. Section 1 of the Act provides the overall foundation for the provisions and regulations that follow:

Since the environment of the Maldives is a valuable heritage that has to be preserved for the coming generations, the Maldivian land, water, vegetations, beaches, lagoons, reefs and similar places 
apart from these, including seas, atmosphere, and in protecting and preserving the creatures living in these places, excluding those that are harmful and pest to human being, the Maldivian government and citizens should give special attention for sustaining and extending the benefits thereof for it is crucial for the sustainable development of the Maldives.

The environment is defined in section 11(a) as 'all living and non-living things that surround and affect the lives of human beings'. Although prospective in terms of considering sustainable development and future generations, it is nonetheless anthropocentric given the strong references to humans. ${ }^{92}$ In achieving these objects, relevant authorities are to provide guidelines and steps to be taken to protect and preserve the environment. ${ }^{93}$ The Act also foreshadows policies and regulations and is thus a framework under which further rules are to be made. ${ }^{94}$ In the absence of another relevant authority it is the Environmental Ministry that must identify 'places and things' that have to be protected, develop regulations and enforce them, although any member of the public can suggest elements requiring protection. ${ }^{95}$ This section has been utilised to declare protected areas in Maldives. The only specific provisions contained in the EPPA relate to prohibitions on disposal of wastes and other substances that 'may have harmful effects on the environment', although exceptions are given where disposal is 'absolutely necessary' and incineration must 'avoid any harm to the health of the population'; neither of which is defined. ${ }^{96}$ Penalties include differential fines for minor and major offences. ${ }^{97}$

Importantly, the EPPA requires reports on environmental impacts to be submitted to the Ministry before commencing projects that might cause 'a potential impact on the environment' ${ }^{98}$ Projects are defined as activities "with the purpose of achieving a certain social or economic objective' ${ }^{99}$ The Ministry is given broad powers to develop guidelines, decide assessments, and terminate projects. ${ }^{100}$ Regulations have been developed through an ADB project, and are far more detailed than other subsidiary legislation, including not only rules for EIA but also an EIA process flowchart, relevant forms, contents of EIA reports, details of potential impacts, certificates of registration and checklists. ${ }^{101}$ Proponents of projects must apply for an 'Environmental Decision Statement'. ${ }^{102}$ Provision is made for factors to be taken into account and they are broad in scope. ${ }^{103}$ Minor proposals are initially screened, and may be approved or required to apply for an 'Initial Environmental Examination'; more significant proposals, as listed in Schedule D, progress directly to an EIA. ${ }^{104}$ The Regulations set out the screening, scoping, initial environmental examination and full EIA processes. Importantly, two independent reviewers undertake the assessments; the Ministry keeps rosters of approved reviewers but the identity of the individuals assigned to any assessment is

92. Sharks have received strong protection in Maldives yet could be considered a pest or harmful to humans.

93. Environmental Protection and Preservation Act (Law No. 4/93) s 2.

94. Environmental Protection and Preservation Act (Law No. 4/93) s 3. For example, Regulation on dredging and reclamation of harbours (2013).

95. Environmental Protection and Preservation Act (Law No. 4/93) s 4.

96. Ibid, $\mathrm{s} 7$.

97. Ibid, s 9 .

98. Ibid, s 5 .

99. Ibid, s 11(b).

100. Ibid, ss 5-6.

101. Environmental Impact Assessment Regulations (2007) schs A-R.

102. Ibid, reg 5 .

103. Ibid, reg 3(2).

104. Ibid, reg 6. 
confidential. ${ }^{105}$ Input is sought from relevant ministries, authorities and the public, and if the project is controversial or complex further public input may be sought. ${ }^{106}$ The decision itself can be to approve the project, refer it back to the proponent, or to reject it (due to a poor quality EIA, unjustifiable environmental cost or significant or irreversible damage). ${ }^{107}$ If approved, ongoing monitoring and mitigation measures are required during the course of the project. ${ }^{108}$ The regulations include appeal procedures, offences and enforcement provisions. ${ }^{109}$ The Ministry is required to keep a list of applications under review and decision statements, and to make them accessible. ${ }^{110}$ The Regulations have been amended four times to date but no English language versions of these newest instruments are yet available.

Other instruments include the Regulation on Migratory Birds (2007) which prohibits activities that could harm seasonal migratory birds ${ }^{111}$ and the Regulation for the Chopping, Uprooting, Removing and Transfer of Palms and Trees between Islands (2006) which seeks to prevent deforestation by prohibiting the removal of coastal vegetation extending 15 metres inland from the outermost trees closest to the beach, including mangroves and wetland species. ${ }^{112}$

The basic environmental legislation together with the comprehensive EIA Regulations provide a firm foundation for decision-making regarding development approvals. Regulations under the Tourism Act (considered below) add to these in relation to hotel and resort construction and operations. In addition, Regulation Governing Reclamation and Dredging of Islands and Lagoons of Maldives (R-15/2013) seeks to minimise impacts of development, restricting sand removal, reclamation or dredging closer than 200 metres (except for a cabinet approved government development project) and adherence to standards. ${ }^{113}$ Nevertheless, there are notable gaps in relation to wildlife conservation, biodiversity law, and protected area management. The Maldivian government has recognised this and steps are being taken to strengthen environmental governance. As noted above, Maldives' NBSAP is one of the key current policy documents outlining planned activities and targets for 2016-25. Strategy One in the NBSAP focuses on improving governance and policies. Two relevant legal indicators are set out: 'By 2020 governance on biodiversity conservation is strengthened at local and national level'; and 'By 2020 enforcement of laws and regulations on biodiversity are strengthened' including by addressing gaps and strengthening environmental police and increasing the number of cases addressed by the Environmental Crime Unit. ${ }^{114} \mathrm{~A}$ further relevant target is to raise awareness of the significance of biodiversity conservation amongst law-makers and decision makers by 2025 , and by 2020 to raise awareness by law enforcement officials (including Maldives Police Service and Coast Guard) of relevant laws. Other actions that refer to legal measures include developing policies, laws and regulations to fill gaps to

105. Environmental Impact Assessment Regulations (2007) reg 10. The Regulations include procedures for appointing consultants as reviewers; they may be foreign nationals with suitable qualifications: regs $14-17$.

106. Ibid.

107. Environmental Impact Assessment Regulations (2007) reg 11.

108. Ibid, reg 13.

109. Ibid, regs 12,18 and 21 respectively.

110. Ibid, reg 5.

111. Republic of Maldives (n 7) 111.

112. Ibid, 198-99.

113. Regulation governing reclamation and dredging of islands and lagoons of Maldives regs 3 and 11 .

114. NBSAP (n 4) 14. 
decrease climate change impacts, amending the 'EIA process to at least halve the rate of loss of habitats during developmental practices' ${ }^{115}$ revising existing regulations and enforce new regulations on threatened species, ${ }^{116}$ identifying gaps and amending regulations to address illegal trade in endangered and protected species, developing laws on access and benefit sharing, and enforcing waste regulations. Cost estimates are provided in that document and in total are likely to be prohibitively expensive. Lack of technical capacity may well also constrain activities and achievements.

\subsection{Fisheries}

Fishing in the Lagoons of Maldives (Law No. 1/74) regulates inshore fishing within lagoons on inhabited and uninhabited islands. Maldivian fishers are permitted to fish in the lagoon of the island in which they live. Permission is required to fish in the lagoon of an inhabited island, by people of another island, and any uninhabited islands. ${ }^{117}$ Power is given to authorities on larger inhabited and uninhabited atolls, to demarcate common fishing areas for off-island inhabitants. ${ }^{118}$ Article 4 protects any 'enclosure for fishing' collectively built by the inhabitants of an island; ensuring off-island inhabitants cannot fish there. ${ }^{119}$ Anyone wanting to enclose an area in a lagoon on an uninhabited island, requires approval and an indication of the managers of the enclosure and the season in which fishing will be conducted. ${ }^{120}$ Interestingly, the collecting of bait is exempted from the Act. ${ }^{121}$

The Fisheries Law of the Maldives (Law No. 5/87) sets out the basic framework for fisheries management by the Ministry of Fisheries, covering the 'fishing, capturing or taking of any living resources' in the EEZ. ${ }^{122}$ The fisheries management regime focuses on licences and approvals. For example, all foreign fishers require permission to fish in the Maldivian EEZ, ${ }^{123}$ fishing exports require a licence from the Ministry of Trade and Industries, ${ }^{124}$ and fisheries research must be approved. ${ }^{125}$ Again specific reference is made to baitfish, essential for the pole and line fishery: under section 6(b)(iv) the catching of baitfish is only permitted using 'vessels and methods traditionally used in the country'. The Ministry of Fisheries also collects, compiles and analyses statistical information and all fishers are required to provide data to assist in this task. ${ }^{126}$ As expected, there are offence and penalty provisions, including the

115. Ibid, 33. See also Shakeela et al (n 3).

116. NBSAP (n 4) 34.

117. Fishing in the Lagoons of Maldives (Law No. 1/74) art 1.

118. Ibid, arts 2 and 3.

119. Ibid, art 4.

120. Fishing in the Lagoons of Maldives (Law No. 1/74) art 5. See also the Aquaculture Regulations, which refer to the 'traditional practice of keeping or holding live fish ... for subsistence, personal or traditional use': reg 5.

121. Fishing in the Lagoons of Maldives (Law No. 1/74) art 6.

122. Fisheries Law of the Maldives (Law No. 5/87) s 2.

123. Ibid, s 5. Any foreign vessel entering the EEZ requires permission even if not fishing: $\mathrm{s} 7$. 124. Ibid, s 6. Such licences may be cancelled if a vessel or person on board has acted 'in a manner that might endanger the peace or security of the country': s 8.

125. Fisheries Law of the Maldives (Law No. 5/87) s 9. General Fisheries Regulations reg 15 extends this by requiring approval for marine scientific research in any Maldivian maritime zone. A later Regulation on the undertaking of marine scientific research in Maldives (2013) further expands on the regulatory framework.

126. Fisheries Law of the Maldives (Law No. 5/87) s 4. Minimum data to be provided is set out in the Schedule to the General Fisheries Regulations. 
creation of rights to stop and board a vessel suspected of illegal fishing, and to confiscate and sell illegal catches. ${ }^{127}$

The Regulation for Issuing the License to Fish in the Exclusive Economic Zone of the Republic of Maldives covers fishing beyond 75 miles from the baselines, and stipulates that such licences will only be granted for pole and line fishing, longlining and trolling. ${ }^{128}$ These licences will not permit bait fishing; which can only be conducted by vessels traditionally engaged in such fisheries. ${ }^{129}$ The government reserves the right to board vessels, station officials on board and train those engaged in such fishing. ${ }^{130}$ Licensees must also supply data and may have their licences revoked in the interests of national security and public order. ${ }^{131}$

The General Fisheries Regulations expand on some of the matters in both of the above Acts. For example, it requires that all Maldivian vessels must obtain approval to fish beyond Maldivian waters. ${ }^{132}$ Fishers from one island require approval to fish from the reefs of other inhabited islands, unless the reef is more than 1,000 metres from the beach, in which case anyone may fish beyond 700 metres from the beach. ${ }^{133}$ Reefs that are not part of an island can be fished by anyone. ${ }^{134}$ Regulation $11(\mathrm{~g})$ makes it clear that nets are not to be used. Interestingly, tourist resorts are empowered to authorise fishing on reefs around the resort, ${ }^{135}$ and the Lagoon Zoning Regulation of Leased Islands for Development of Tourist Resorts, Tourist Hotels, Tourist Guesthouse and Yacht Marina has restricted local people's access to marine areas close to these resorts. ${ }^{136}$

The General Fisheries Regulations ban the use of dynamite, poison and guns, as well as more specific activities: collecting sea cucumber and lobster with scuba gear, nets to catch mackerel and small reef fish, as well as trawling in some areas. ${ }^{137}$ It is this provision that was initially used to prohibit shark fishing in the territorial sea. ${ }^{138}$

In addition to general licensing and management the Fisheries Law of the Maldives provides in section 10 that

[i]n the event of a special need for the conservation of any species of the living marine resources, the Ministry of Fisheries shall have the right to prohibit, for a specified period, the fishing, capturing or the taking of such species or the right to establish special sanctuaries from where such species may not be fished, captured or taken.

The General Fisheries Regulations expand on these provisions by prohibiting the 'catching, fishing, collecting or killing' within the EEZ of dolphins, whales, female

127. Fisheries Law of the Maldives (Law No. 5/87) ss 11-13.

128. Regulation for Issuing the License to Fish in the Exclusive Economic Zone of the Republic of Maldives reg 5.

129. Ibid, reg 6.

130. Ibid, regs $12-14$.

131. Ibid, regs $15-17$.

132. General Fisheries Regulations reg 4.

133. Ibid, reg 11.

134. Ibid, reg 11(f).

135. Ibid, reg 11(d).

136. See Shakeela et al (n 3) 23.

137. General Fisheries Regulations reg 12.

138. Ibid, reg 12(9). Since 2011 shark fishing has been banned in all Maldivian waters effectively creating a shark sanctuary. 
lobsters, ${ }^{139}$ triton shell, giant clam, black coral, whale shark, napoleon wrasse and sea turtles and their eggs. ${ }^{140}$ The General Fisheries Regulations also regulate the use of fish aggregating devices specifically prohibiting baited line fishing, trolling and shark fishing within three miles of a device, ${ }^{141}$ as well as outlawing the breeding of turtles. ${ }^{142}$

The Fisheries laws are both a number of decades old and despite efforts to reform them, no new legislation has been forthcoming. The adoption of the Aquaculture Regulations, which are contemporary and comprehensive, suggests that any new developments are likely to be in subsidiary legislation. These Regulations include detailed provisions for aquaculture licences, pollution and disease prevention, import of fish and quarantine, aquaculture research, record keeping and reporting. All aquaculture, except traditional practices, requires a licence issued on completion of a comprehensive application. ${ }^{143}$ Significantly, licence holders are subject to general duties and detailed regulations are included to prevent discharge of waste including prohibiting wastewater discharges into Maldivian waters and requirements for effluent reservoirs. ${ }^{144}$ The Regulations are quite prospective, for example, allowing the Minister to require deposits from licence holders towards the costs of removing aquaculture facilities at the end of life. ${ }^{145}$ Record keeping is a focus, not only with respect to stocking and sale of products, but also feed, diseases, medication and other data. ${ }^{146}$ Additional provisions seek to address the risk of disease and invasive species introduction through quarantine requirements, environmental assessment and health certification, inspection, detection and destruction in the event of disease, as well as lists of living organisms prohibited and restricted from import. ${ }^{147}$ The Regulations envisage the appointment of aquaculture inspectors, and the establishment of designated aquaculture facilities, infected and surveillance zones. ${ }^{148}$

The Ministry of Fisheries and Agriculture also has responsibility for the Law on Stone, Sand and Coral Mining in Inhabited Islands (Law No. 77/78) which creates a permit system for approval to mine coral, sand and stones from inhabited islands, and an exemption for leased and uninhabited islands, which has allowed trade to continue. ${ }^{149}$ The Regulation on Mining of Stone, Sand and Coral (2000) establishes a system of designated areas and adds to the permission regime for islands and birdnesting sandbars. ${ }^{150}$ The Regulation on the Protection and Conservation of

139. Female lobsters with eggs under their stomach and any lobster smaller than 35 cam from head to tail: ibid, reg 13(3).

140. Ibid, reg 13.

141. Ibid, reg 18.

142. Ibid, reg 19.

143. Aquaculture Regulations regs 4-9.

144. Ibid, regs 10-11.

145. Ibid, reg 19.

146. Ibid, reg 25 .

147. Ibid, regs 29-47.

148. Aquaculture Regulations regs 49 and 55. In the Report to the CBD, reference is made to new fisheries regulations introduced in 2010 - Regulation for Fishing Licensing, Fish Processing for Exports and Aquaculture and Regulation on Fishing and Export of Large Yellow fin Tuna - but copies of these laws are not available: Ministry for Environment and Energy (n 62). 149. See Shakeela et al (n 3) 26, 46-47.

150. Republic of Maldives (n 7) 198. The earlier Regulation on Coral Mining (1990) only applies to coral mining from the 'house reef' of islands and atoll rim reefs: Republic of Maldives Ministry for Environment and Energy, Executive Summary of the Maldives Clean Environment Project Environmental and Social Assessment and Management Framework (ESAMF) 
Environment in the Tourism Industry (RPCETI) protects coral, prohibiting its removal from any part of the lagoon or reef in Maldives leased for tourism or from any reef to repair any jetty or breakwater. ${ }^{151}$

There is no comprehensive fisheries policy in Maldives yet a number of policies, plans and programmes relate to fisheries, mostly in the context of conservation to maintain ocean health, the fishing industry and food security. ${ }^{152}$ The shift to elevate tourism above fishing concerns is most evident in relation to sharks. Despite having a traditional shark fishery by the 1990s it had declined, and evidence indicated that loss of sharks from dive sites could negatively impact on the tourism sector. ${ }^{153}$ Maldives banned fishing for whale sharks in 1995 and longlining for sharks in 1996 and 1997; followed by a ten-year moratorium on shark fishing in 1998, a total ban in territorial waters in 2009, and the entire EEZ in $2010 .{ }^{154}$ In 2015 Maldives adopted a National Plan of Action including 'actions to strengthen the current management measures and propose further actions necessary for sustainable non-extractive utilization of shark resources'. ${ }^{155}$ This incremental approach demonstrates changing attitudes, a recognition of environmental impacts and a desire to secure the health of sharks for the tourism industry.

\subsection{Tourism}

The first law referring to tourism was the Maldives Foreign Investment Act (Law No. 25/79) and this was later followed by the Maldives Uninhabited Islands Act (Law No. 20/98). ${ }^{156}$ The first legislation focusing squarely on the sector is the Tourism Act (Law No. 2/1999) with efforts to contain negative effects addressed by the RPCETI. The Tourism Act itself does not impact greatly on the development of environmental law, but does establish a regime for determination of zones and islands for tourism, as well as arrangements for resorts, marinas and diving centres. The Ministry of Tourism (now Ministry for Tourism and Civil Aviation) has the discretion to classify resorts, hotels, guesthouses and vessels and to monitor all facilities (including dive centres, marinas and travel agencies) to ensure compliance with guidelines. ${ }^{157}$ Provisions set out the framework for leases and licences for tourist resorts, hotels, guesthouses, marinas, tourist vessels and dive centres. Importantly, when a tourist resort ceases to operate it must be returned to the Government in the same condition as when it did operate; ensuring derelict facilities are not left on islands. ${ }^{158}$ Licences are required for all tourist activities and some further control is maintained through requirements that

\& Resettlement Policy Framework (RPF) (2016) <http://documents.worldbank.org/curated/en/ 137111487714352928/FINAL-MCEP-ESAMF-Exec-Summary-Clean-2-3-17-02172017. docx>, 26.

151. Regulation on the Protection and Conservation of Environment in the Tourism Industry regs 2.13 and 2.15 .

152. See for example, Republic of Maldives (n 7) 23; NBSAP (n 4) 7.

153. RC Anderson and Hudha Ahmed, The Shark Fisheries in the Maldives (Ministry of Fisheries and Agriculture, Republic of Maldives and FAO, 1993).

154. Republic of Maldives (n 76) 2.

155. Ibid, 8.

156. Shakeela et al (n 3) 8-9.

157. Tourism Act (Law No. 2/1999) ss 44-45.

158. Ibid, s 7(a). The monetary value of the resort facilities will not be paid by the Government: s 7(c). 
companies applying for a tourist resort lease must be registered in Maldives, ${ }^{159}$ as must vessels and dive centres. ${ }^{160}$ There are few environmental provisions, though section 15 mandates approval from the Ministry for Tourism and Civil Aviation for the felling of trees, reclamation of land and dredging of lagoons as well as activities 'likely to cause a permanent change to the natural environment' ${ }^{161}$ One provision of note is section 14(a) which allows the Government to take possession of an island or land used for tourism where it is required for 'defence of the Maldives'; it is unclear whether defence means only military purposes or could include protection against the effects of climate change.

The RPCETI supplements the Act '...to protect the environment in the tourism industry and to facilitate sustainable development of tourism'. ${ }^{162}$ The Regulations expand on the list of activities requiring permission: felling of trees, dredging of lagoons or reefs, construction of seawalls and breakwaters, beach enhancement and construction on the beach and lagoon are included as well as importing or exporting living species, research or 'anything which may adversely affect the vegetation or fresh water lens of the island'. ${ }^{163}$ It is unclear whether this extends to dredging or construction for climate resilience if it is in the vicinity of a resort, or only if it is required for tourism purposes. Indeed Regulation 2.2 states that 'any activity that may cause damage or adversely affect the environment' requires approval from the Ministry. Beyond the construction phase, protection is offered over both land and marine protected species: 80 percent of any island must remain un-built (calculated inland from the vegetation line), any tree felled must be replaced with two more, 'huge, aged or rare trees' cannot be felled and a buffer zone of five metres must be retained around them, extraction of coral stones is prohibited. ${ }^{164}$ Furthermore, protected birds or marine living species cannot be caught or kept in cages, activities that would harm protected species (including their habitats and eggs etc.) are prohibited, and no harm should be caused to any marine flora and fauna in diving areas. ${ }^{165}$ Specific provisions are included with respect to protected areas: renovations, improvements or alterations are not permitted, neither is anchoring a vessel in a protected area, and any sites, structures or objects of historical, cultural or environmental significance must be maintained. ${ }^{166}$ Further provisions are included with respect to waste management, storage of water, and sewage treatment. ${ }^{167}$ There appear to be no offence or penalty provisions that could be used against a tourist that breaches the regulation. ${ }^{168}$

The Maldives Recreational Diving Regulation (2003) recognises the importance of scuba diving to the tourism industry and sets standards to ensure safety. The Regulation prescribes minimum certification requirements, rules regarding supervision during dive activities, depth and decompression limits, procedures for the dive itself as well as standard equipment provided during activities and other gear that must be

159. Ibid, s 9.

160. Ibid, ss 23 and 29.

161. Such approval will only be given after an EIA and evidence that the activity is 'fundamental': ibid, s 15.

162. Regulation on the Protection and Conservation of Environment in the Tourism Industry reg 1.4 .

163. Ibid, reg 2.1. Reg 2.4 requires an EIA before approval will be given.

164. Ibid, reg 2.

165. Ibid, reg 3.

166. Ibid.

167. Ibid, regs $5-7$.

168. Shakeela et al (n 3) 82 . 
available at dive centres and on dive boats. ${ }^{169}$ Emergency plans and procedures must be formulated and dive centre staff fully qualified. ${ }^{170}$ Significantly, it includes a 'look but don't touch' rule in relation to wrecks and objects, prohibition of removal of underwater cultural heritage and obligations to protect the marine environment. ${ }^{171}$ The instrument does not, however, contain offences and penalty provisions.

Maldives has adopted a series of Tourism Master Plans, commencing in 1983. The Fourth National Tourism Master Plan 2013-2017, makes a number of references to the law including potential reform of the leasing, implementation and monitoring sections, and harmonisation with other laws. ${ }^{172}$ The majority of areas for law reform relate to employment, foreign direct investment and company law, as well as mortgages and taxation. ${ }^{173}$

\section{LAW IN ACTION}

The above analysis outlines the different laws and regulations that exist in Maldives. The question remains as to how well these laws are working and, in particular, whether they are being implemented and enforced. Based on the limited information available effectiveness appears to be mixed, although it is acknowledged that finding regulations, and listed sites and species, have been hampered by language barriers. ${ }^{174}$

The incremental adoption of stronger EIA provisions demonstrates a commitment to develop an effective legislative framework, supported by detailed regulations. Nonetheless, although the laws seek to preserve the environment and minimise undesirable impacts, commentators have noted that lack of capacity, resources and trained personnel, combined with the complex legal landscape, have hampered achievements. ${ }^{175}$ Critical reviews of the EIAs indicate that they 'only seem to barely fulfill the current mandatory requirements' and procedure 'lacks transparency, responsiveness and accountability...', ${ }^{176}$ with timeframes being so short EIAs 'are generally done in a rush'. ${ }^{177}$ Although commentators have called for a more 'comprehensive framework for assessing and monitoring tourism impacts' this was before the adoption of the most recent EIA regulation amendments. ${ }^{178}$ While the provisions appear to be inclusive and transparent, 'from a procedural perspective, the practice of EIA did not meet many of the investigated conditions for fairness and competence' and 'socio-economic barriers were identified which have an impact on the willingness

169. Maldives Recreational Diving Regulation (2003) chap 2, regs 1-8.

170. Ibid, chap 2, regs 9-10.

171. Ibid, chap 3, regs 11-13.

172. Ministry of Tourism, Arts \& Culture (n 31) 23-27.

173. Ibid, 26.

174. There are no easily accessible comprehensive lists of species or sites. Nor is there a single website or database where all legislation can be found. The Government Gazette online and the Attorney-General's office, for example, are in Dhivehi: <www.gazette.gov.mv/> and <www. agoffice.gov.mv>.

175. Shahida Zubair, David Bowen and James Elwin, 'Not Quite Paradise: Inadequacies of Environmental Impact Assessment in the Maldives' (2011) 32 Tourism Management 225, 229. 176. Ibid, 231.

177. Aishath Niyaz and Donovan Storey, 'Environmental management in the absence of participation: a case study of the Maldives' (2011) 29(1) Impact Assessment and Project Appraisal 69, 74 .

178. Zubair et al (n 175) 232. 
and capacity of the different actors to facilitate or participate in public meetings' ${ }^{179}$ Even the Third National Environment Action Plan recommended further public education and other initiatives to fully enable the public consultation elements of the EIA process. ${ }^{180}$ Other commentators have also made reference to the lack of public participation: although complex and controversial projects require public consultation, these words are not defined ${ }^{181}$ and limited weight is given to the public participation component. ${ }^{182}$ Other identified future issues include the need for standards and guidelines for infrastructure development including high impact coastal development activities. $^{183}$

In terms of biodiversity conservation, the EPPA has resulted in a number of protected areas. The first protected areas were declared in 1995, and this has grown to a total of $244 \mathrm{sq} \mathrm{km}$ set aside for conservation under the Act in a total of 42 protected areas and one biosphere reserve (Baa Atoll). ${ }^{184}$ The Baa Atoll is an administrative area in Maldives and has declared six MPAs adding to two earlier declarations within its borders. ${ }^{185}$ Two islands have also been declared protected islands: Hithaadhoo (North Huvadu Atoll) and Hurasdhoo (South Ari Atoll), ${ }^{186}$ and recently three further protected islands have been announced. ${ }^{187}$ However, only one area in Maldives appears to be managed with an effective management regulation, drawing attention to the need for further research to assess effective implementation of the law across all 42 areas. ${ }^{188}$ In the ocean environment the largest protected area is the South Ari Atoll MPA (SAAMPA) attracting over 65,000 visitors a year. This is an important aggregation site for whale sharks, however its designation has not yet led to a management plan or enforced regulations. It has been suggested that a draft management plan is being developed which will, amongst other things, regulate access and use of

179. Mohamed Hamdhaan Zuhair and Priya A Kurian, 'Socio-economic and Political Barriers to Public Participation in EIA: Implications for Sustainable Development in the Maldives' (2016) 34(2) Impact Assessment and Project Appraisal 129, 139.

180. Ministry of Housing, Transport and Environment, Government of Maldives, Third National Environmental Action Plan, 2009-2013 (UNEP, 2009) 12.

181. Zuhair and Kurian (n 179) 131.

182. Niyaz and Storey (n 177) 74.

183. Ministry of Housing, Transport and Environment (n 180) 6, 12.

184. Republic of Maldives (n 7) 23 and 113. For details of 36 marine protected areas see Atlas of Marine Protection, 'Maldives' <www.mpatlas.org/region/country/MDV/>. See also Mohamed Sajid, 'UNESCO Declares Baa Atoll A Biosphere Reserve' (Maldives Insider, 30 June 2011) <http://maldives.net.mv/1656/unesco-declares-baa-atoll-a-biosphere-reserve/>. See also, 'Birds, Dive Sites, Areas and Islands Protected under The Environment Protection and Preservation Act, (Act 4/93) of Maldives' <www.broffice.gov.mv/en/files/mald_protected. pdf $>$.

185. New declarations include Mendhu Island, an area in Maahuruvalhi Faru, Mathifaruhura Island including house reef, Bathalaahura Island including house reef, Gaaganduhura Isand including house reef and Vinanehfaruhura Island; extensions of existing MPAs are in the higalihaa area and around Hanifaru Island: Mohamed Sajid, 'Six Marine Areas in Baa Atoll Declared as Protected' (Maldives Insider, 6 June 2011). <http://maldives.net.mv/1207/sixmarine-areas-in-baa-atoll-declared-as-protected/>.

186. UNESP/SACEP/NORAD (n 1) 65.

187. Rasdhoo-Madivaru area in the central Alif Alif atoll, Farukolhu island in the northern Shaviyani atoll and Dhigulabaadho, in the Gaaf Dhaal atoll: 'Environment Ministry Declares Three New Protected Areas' (Maldives Independent, 9 October 2018) <https://maldivesindependent. com/environment/environment-ministry-declares-three-new-protected-areas-141940>.

188. NBSAP (n 4) 10. 
the MPA including the number of whale shark tourism operators and visitors. Despite these advances there has been no dedicated protected area legislation developed, although there has been a Maldives Protected Area Systems project. It appears that this may now have been rectified with the announcement of a new Regulation which hopefully includes detailed arrangements as seen with respect to aquaculture and EIA. ${ }^{189}$

Furthermore, it has been noted that in the local Dhivehi language 'protected' translates to 'untouchable', which may have led some fishers to believe that the designations of marine areas favour tourism over fishing; combined with a lack of consultation at the time of the declarations this has caused misunderstandings and lack of compliance. ${ }^{190}$ This is not assisted by the preparation of a 'sensitive area list' with 274 environmentally significant areas being identified by the Environmental Protection Agency. ${ }^{191}$ These areas appear to be given careful consideration before approval of any type of development, but are not protected under law.

In addition to areas, certain species have received attention. Sharks have been protected in all waters and other species have also been fully protected including marine mammals, sea turtles, giant clams, lobsters, and black coral. 103 bird species have been protected under the EPPA along with three land and marine species; nine other marine species are protected under the Fisheries Law. ${ }^{192}$ A migratory birds regulation, which gives protection to all such species, has been in effect since 2014. A further regulation controls the import of bird species as pets. In spite of this regulation, and the RPCETI which prohibits protected birds from being caught or kept in cages, many exotic birds (protected by this law) continue to be imported illegally. ${ }^{193}$ The declaration of Baa Atoll as a UNESCO Biosphere Reserve in 2011, appears to have been influential leading to the announcement that the whole country will be made a Biosphere Reserve. ${ }^{194}$

In relation to fisheries, the traditional pole and line tuna fishery appears to be a success; it has recently received the Marine Stewardship Council (MSC) certificate with respect to Skipjack Tuna. ${ }^{195}$ The grouper fishery, commenced in 1992 has had mixed success with the government enforcing a ban on fisheries in ' 5 areas significant for grouper breeding' and a 'licensing system for grouper fishing vessels was introduced in 2012'. ${ }^{196}$ Again, the laws are in place to provide for fisheries management but detailed plans are still being developed with respect to most areas.

189. Ahmed Aiham and Rae Munavvar, 'New Environment Regulation Grants Powers to EPA, Protected Islands' (The Edition, 7 August 2018) <https://edition.mv/news/6747>, referring to R-78/2018. Copies of the Regulation are not yet available.

190. A Rifaee Rasheed, Ameer Abdulla and Nabeeh I Zakariyya, 'Vulnerability of Different Types of Fishers to Potential Implementation of a Management Plan in a Marine Protected Area (MPA) in the Maldives' (2016) 74 Marine Policy 195-204.

191. See for example, Ministry for Environment and Energy, 'Environmental Impact Assessment for the construction and setup of a sewerage system in Makurathu Island, Raa Atoll, Maldives' (Environmental Impact Assessment, 2017) 24.

192. Republic of Maldives (n 7) 119.

193. NBSAP (n 4) 17.

194. Ministry of Environment and Energy, 'Maldives as a Biosphere Reserve' (2013) <www. cbd.int/doc/world/mv/mv-biosphere-reserve-en.pdf $>, 6-7$, quoting the President of Maldives Dr Mohamed Waheed's speech of 20 June 2012 at the RIO+20 Meeting of the UN Conference on Sustainable Development.

195. NBSAP (n 4) 10.

196. Ibid. 
There is little doubt that tourism has allowed revenue to be generated with less impact than extractive industries. Nonetheless there are risks, which the laws limiting development of islands to 20 percent of the land area, together with strict construction and pollution regulations, seek to minimise. Furthermore, the NBSAP indicates that 112 resort islands have restrictions around island areas, which extend to $1 \mathrm{~km}$ from the shoreline. In some cases activities are limited just to snorkelling. ${ }^{197}$ These resort areas, like the sensitive areas note above, may be effective in some contexts but are not legally enforceable, nor do they appear to be formally monitored.

\section{ANALYSIS AND RECOMMENDATIONS}

The above analysis indicates that there is a body of environmental and fisheries law which together with the tourism legislation creates a foundation for good environmental governance. In terms of the legal texts themselves, some of this legislation is quite old and minimalist in scope. Although detailed regulations have been adopted in the areas of EIA and aquaculture, others are missing, leaving gaps in the overall legislative framework. This has been recognised in Maldives as targets were set to review all existing environmental law and policy and propose recommendations for reform by $2010 .{ }^{198}$ It does not appear that this was completed, and since then Regulations have been promulgated under existing legislation, rather than law reform being initiated. This piecemeal approach is unlikely to achieve the most efficient and effective outcomes at the intersection of conservation, fisheries and tourism; some specific aspects are considered below.

Further research is required to fully assess the effectiveness of existing law, before detailed recommendations for reform can be made. Nevertheless, where basic definitions are not included in legislation this is likely to hamper effectiveness. For example, under the Regulation on Projection and Conservation of Environment in the Tourism Industry, Regulations 2.10 and 2.12 both refer to land areas inwards of the vegetation line, but no definition of 'vegetation line' is provided. ${ }^{199}$ The same instrument requires waste disposal in a manner that will have 'least impact'; this phrase is not defined. ${ }^{200}$ Other omissions include offence and penalty provisions: Regulation 3.7 requires that no harm is done to flora and fauna in diving areas, but there appear to be no repercussions for breach. The Maldives Recreational Diving Regulation (2003) includes similar prohibitions on harming the marine environment and damaging wrecks, but again for offences or penalties are provided. ${ }^{201}$

A fully functioning marine protected area system has been identified as important but has not yet emerged. ${ }^{202}$ Area-based laws are critical for conserving terrestrial spaces as well as the marine environment. The Third National Environmental Action Plan, 2009-2013 set a target of 20 representative islands to be designated by 2011 together with management plans for national protected areas, atoll protected areas

197. Ibid, 9.

198. Ministry of Housing, Transport and Environment (n 180) 20.

199. Interestingly the Regulation for the chopping, uprooting, removing and transfer between islands of palms and trees utilises the phrase 'inward ... from the outermost trees closest to the beach': see reg 3 .

200. See comments in Shakeela et al (n 3) 30, 31 and 37.

201. Shakeela et al (n 3) 35-37.

202. Ministry of Housing, Transport and Environment (n 180) 11. 
and private land under conservation agreements; it is unclear whether this has been achieved. ${ }^{203}$ Wetlands have also been identified as requiring attention to determine significance, prepare management plans and introduce legislation. ${ }^{204}$ It would appear that there is sufficient justification for developing a protected area regulation along similar lines to the aquaculture and EIA Regulations. One constraining factor will be integrating provisions by which areas can be protected under the EPPA, Fisheries Law and Tourism Law. Recent announcements indicate that a new instrument to conserve protected areas, nature reserves and biodiversity has been adopted, updating classifications (internationally protected areas, strict nature reserve, wilderness areas, national park, natural monument, habitat/species management area and protected areas with sustainable use) and providing new regulations including the establishment of a registry of declared areas and a right to levy fees for access. ${ }^{205}$ Any new regulations that are adopted must be fully implemented and their effectiveness assessed. It appears that non-governmental organisations and not-for profit bodies, working at the grassroots level, have been influential in raising awareness, training and information sharing, and taking action on the ground with respect to environmental protection. ${ }^{206}$ Their role is likely to remain significant vis-à-vis central government.

Integration is a significant challenge in Maldives with three Ministries having responsibility for different elements of environmental protection. There is no doubt that the Ministry of Environment and Energy is the most significant, but given the law and policy interlinkages some attention must be paid to integrating portfolios and laws. For example, there is a divide between the mandates of the environment and tourism ministries on resort island matters, and between environment and fisheries ministries with respect to marine management. Within the legislation, the Fisheries Act permits marine extraction, but local access to the marine environment near resorts is restricted under the Lagoon Zoning Regulation of Leased Islands for Development of Tourist Resorts, Tourist Hotels, Tourist Guesthouse and Yacht Marina. ${ }^{207}$ The arrangements for the felling of trees is also complex: five instruments refer to permissions needed and/or replacement planting. One particular challenge is coral reef management, where gaps and barriers and a clear division of mandates have been acknowledged. Strategic goals have been identified, including completing a review of institutional frameworks and the development of an enabling regulatory regime, given the current lack of coordination and regulation. ${ }^{208}$ A conflict could arise in relation to coral mining, permitted under one Act and prohibited under regulations. This again is an area where a comprehensive regulation could be developed that sets out roles and responsibilities together with tailored rules for these specific habitats. The Fifth National Report to the CBD suggests that such a regulation exists as the goal is set to '[e]nable the enforcement of existing coral reef management regulations';

203. Ibid, 13.

204. Ibid.

205. Aiham and Munavvar (n 189).

206. Republic of Maldives Ministry of Environment and Energy, State of the Environment Report 2016 (n 7). See also Tundi Agardy, Frank Hicks, Fathimath Nistharan, Abdulla Fisam, Ameer Abdulla, Amir Schmidt, Gabriel Grimsditch, Ecosystem Services Assessment of North Ari Atoll Maldives (IUCN, 2017).

207. Shakeela et al (n 3) 22-23.

208. Ministry of Housing, Transport and Environment (n 180) 11. 
but the authors have been unable to find such a regulation. ${ }^{209}$ This is related to the protected area management issue as the ability to designate zones and address competing uses is critical. ${ }^{210} \mathrm{~A}$ coral reef management regulation could be the first step towards marine spatial planning rules.

One of the most obvious areas in need of review and reform is the biodiversity law. The pressures of economic development and population growth have negatively impacted on the species and habitats through overharvesting, pollution from agriculture, the introduction of alien species, land clearing. ${ }^{211}$ The NBSAP notes major threats of habitat loss including reefs, lagoons, beaches and mangroves, due to coastal development such as land reclamation, harbour and seawall construction with estimates that ' 202 artificial harbours have been constructed and over $10 \mathrm{sq} \mathrm{km}$ of lagoon and reef area modified for land reclamation purposes'. ${ }^{212}$ Maldives has itself noted that its advances made in conservation may be eliminated by increasing pressure on biodiversity in particular, leading to NBSAP strategy one - to strengthen governance and policies. ${ }^{213}$ Specifically identified was a 'lack of understanding of roles and responsibilities coupled with the weak inter-institutional cooperation' as well as '[m] andate overlaps, gaps and conflicts' ${ }^{214}$ Further identified areas requiring attention include identification of threatened species and ecological communities, recovery plans and integration of biodiversity conservation in atoll development plans. ${ }^{215}$ Other needs identified over the last decade include a policy research paper on the economic value of biodiversity conservation, and integration of biodiversity conservation in provincial development strategies, as well as a review of legislative and regulatory frameworks including removal of incentives that encourage biodiversity loss. ${ }^{216} \mathrm{Leg}$ islative reform has been encouraged to review the law in critical areas including economic instruments and incentive measures. ${ }^{217}$

Maldives also does not have a comprehensive forestry Act, nor law on access and benefit sharing of genetic resources. Significant deforestation has occurred in the past, often to clear land for agriculture, although commercial and subsistence harvesting of timber may not be a current threat. Clearing for tourism developments is a risk addressed in part by section 15 of the EPPA and regulation 2.5 of the RPCETI, by which permission is needed to fell any palm or tree. The Regulation on Cutting, Uprooting, Removing and Transfer of Palms and Trees between Islands (2006) permits the felling and/or relocation of trees for 'essential purposes' provided that two new trees are planted in its place. ${ }^{218}$ Lack of recognition and safeguarding of traditional knowledge relating to biodiversity and farming, fishing, medicine and food is another gap that has been identified. ${ }^{219}$ It is clear that if governance is to be enhanced then further law and policy is needed.

209. Ministry for Environment and Energy (n 62) 100.

210. Ministry of Housing, Transport and Environment (n 180) 11-12.

211. NBSAP (n 4) 7-8.

212. Ibid, 7.

213. Ibid, 11 .

214. Ibid, 13.

215. Ministry of Housing, Transport and Environment (n 180) 13.

216. Ibid, 10-11.

217. Ibid, 11.

218. Regulation on Cutting, Uprooting, Removing and Transfer of Palms and Trees between Islands (2006) ss 2-3.

219. Ministry for Environment and Energy (n 62) 53. 
Invasive species is another growing concern, initially identified in the Third National Environmental Action Plan, 2009-2013 where targets were set to develop a risk assessment process for the import of live organisms, programs put in place to manage invasive species and quarantine laws approved and publicized. ${ }^{220}$ Some advances have been made through the adoption of the Aquaculture Regulations, but this leaves open the issue of introductions though bio-fouling and ballast water. Maldives has ratified the Ballast Water Management Convention which could provide a framework for implementation of standards and rules to address introduction of invasive species via shipping.

The impacts of climate change are a significant concern for Maldives. ${ }^{221}$ This article has not focused on the policy development to any great extent, but the need for a new Climate Change Act has been noted as well as resources to advance adaptation plans. Beach erosion is already said to affect 60 percent of the inhabited islands. ${ }^{222}$ The NBSAP notes that no ecosystem-based approach has been identified to address erosion, and seawalls are the main protection measures. ${ }^{223}$ This is clearly an area for research as this type of coastal infrastructure impacts negatively on the environment. Building climate resilience in coastal areas will need to be done in ways that do not breach existing laws; such as the requirements under the RPCETI.

In terms of implementation, it has been said that 'despite progress, the legal and institutional framework is not very well coordinated and some of the existing environment laws are not properly enforced'. ${ }^{224}$ An example is highlighted by Rasheed et al in which they note that although MPAs should be the highest form of protection, they exist as 'paper parks' with only a potential management plan. ${ }^{225}$ Enforcement is a perennial problem in environmental and fisheries law, and is particularly challenging for developing countries. This is an acknowledged problem in Maldives, ${ }^{226}$ and overcoming it is especially difficult because of the large number of islands, concentration of populations and government on one island, and vast ocean areas. A new regulation appears to have been promulgated in 2011, focused on liabilities and compensation, in an effort to prevent violations of the EPPA and punish offenders. ${ }^{227}$

In addition to legislative gaps, it has been observed that ' ... both a lack of political will and budgetary constraints appear to hinder the effective implementation of the marine protection law on the part of the Maldivian government'. ${ }^{228}$ Funding is a critical issue in a SIDS such as Maldives. One way to provide financial resources may be to charge international visitors a levy as they benefit significantly from environmental

220. Government of the Maldives (n 180) 14. The quarantine law goals were repeated again in 2015 implying they had not yet been achieved: Ministry for Environment and Energy (n 62) 103.

221. NBSAP (n 4$) 7$.

222. Ibid, 7. See also Shakeela et al (n 3).

223. NBSAP (n 4) 10.

224. Zubair et al (n 175) 229.

225. Rasheed et al (n 190) 196.

226. Ministry for Environment and Energy (n 62) 52. See also Shakeela et al (n 3) 25-26, referring to empirical evidence of poor compliance and enforcement.

227. Regulation for determination of penalties and obtaining compensation for damages caused to the environment (2011) referred to in Republic of Maldives (n 7) 199. The authors were unable to obtain a copy.

228. Mahadev G Bhat, Ramachandra Bhatta and Mohamed Shumais, 'Sustainable Funding Policies for Environmental Protection: The Case of Maldivian Atolls' (2014) 16 (1) Environmental Economics and Policy Studies 45-67, 46. 
protection and the rich natural heritage of the country. This would be preferential to further financially burdening the local community and government. This would provide funding sourced 'from the group who directly benefit from tourism and the tourism dollars', and support policies designed 'to ensure appropriate money transfer from beneficiaries to those responsible for conservation and regulation' being the environmental agencies tasked with conservation and protection. ${ }^{229}$ Suggestions include a 'one-time conservation fee to be collected at the time of arrival/departure and expenditure taxes on either hotels, food and beverages or underwater recreational activities' ${ }^{230}$ Other opportunities exist to generate financial resources, including through the development of cultural tourism, although this is not compatible with enclave tourism which dominates in Maldives. ${ }^{231}$

Waste management also remains a significant challenge, and one that is likely to worsen as tourism facilities and visitor numbers grow. Strong and effective legislation is needed if impacts such as pollution, including land-based marine plastic pollution, are to be avoided. Although not the focus of this article, the challenge of waste management must not be forgotten.

\section{CONCLUSIONS}

Maldives is perhaps best-known today as a tourist destination; for its beautiful beaches and pristine waters. From a legal perspective it is a jurisdiction about which little academic research has been undertaken. This article contributes to the literature by providing a desk-based review of existing environmental law that can provide a foundation for further study and empirical research. There is no doubt that Maldives has engaged with the international community in relation to environmental issues, evidenced by its treaty ratifications and membership of key institutions, and has also made significant efforts to put in place laws and regulations to protect the environment and conservation and sustainably utilise national resources. This provides a firm basis for future environmental law developments.

The first efforts to regulate resource extraction were adopted in the 1970s followed by the establishment of the first environmental ministry in the 1990s. A new Constitution in 2008 included a 'fundamental duty of the state to protect and preserve the biodiversity, resources and beauty of the country for the benefit of present and future generations' as well as ensuring every citizen has the right to a safe environment. ${ }^{232}$ A similar pattern of incremental development can be seen in the areas of EIA and shark conservation. Thus, Maldives can demonstrate four decades of efforts to enhance its environmental governance, no small achievement for a SIDS.

The most recent Maldivian environmental policy document, the NBSAP, reflects upon challenges and articulates a number of actions and targets related specifically to law reform and enforcement. Although Maldives has received a reasonable share of international assistance, this has not tended to be in the area of building legal capacity; there is perhaps more the international community can do in this regard. One of the main challenges to achieving the ambitious aims of the NBSAP and ensuring law

229. Ibid, 47.

230. Ibid, 64 .

231. Shakeela et al (n 3) 83 .

232. Republic of Maldives Constitution 2008 art 22. 
is 'directed and harmonised" 233 is the 'lack of trained lawyers on the field of environmental law and international environmental governance'. ${ }^{234}$ Legal capacity is a critical aspect in improving environmental outcomes in Maldives. Building local capacity would allow Maldives to take advantage of regionally relevant law and policy examples and draw upon them in filling legislative gaps, particularly by examining successful legal provisions in other SIDS. While it is unlikely laws can simply be transposed from another jurisdiction, options and ideas can be elucidated from them.

Maldives has outstanding natural heritage that continues to attract growing global tourism interest; and provides areas of importance to many migratory species. It is also an unusual legal jurisdiction as a legacy of its history. It is hoped that with greater international and regional cooperation and assistance, Maldives can strengthen its governance of natural resources, species and areas, and achieve its biodiversity conservation goals.

233. NBSAP (n 4) 13.

234. Ibid, 18. 